\title{
(SEBUAH UPAYA) MEMAHAMI MAZMUR KUTUKAN
}

\author{
Stefanus Kristianto
}

\begin{abstract}
Abstraksi: Kitab Mazmur merupakan salah satu kitab dalam Alkitab yang paling disukai orang Kristen. Akan tetapi, beberapa bagian dalam kitab ini-yang biasa disebut Mazmur Kutukan-telah menimbulkan problem etis bagi pembacanya, sebab mazmurmazmur ini nampak bertentangan dengan prinsip kasih yang diajarkan Yesus. Beberapa sarjana memang pernah mengemukakan beragam interpretasi untuk "menjinakkan" mazmur-mazmur ini. Akan tetapi, usulan-usulan tersebut justru menimbulkan masalah lain. Dalam tulisan ini, penulis mencoba menawarkan penafsiran alternatif terhadap mazmur-mazmur kutukan, yakni memahami mazmur-mazmur tersebut dalam terang perjanjian Musa. Menutup tulisan ini, penulis akan memberikan dua aplikasi praktis dari interpretasi tersebut.
\end{abstract}

Kata-kataKunci:Kitab Mazmur, Mazmur Kutukan, Perjanjian Musa, Perjanjian Lama, Etika, Etis

Abstract: The book of Psalms is one of Christian's most favorite books in the Bible. But, some parts of this book-the so-called Imprecatory Psalms-have induced ethical problem for its readers, since they seem to contradict the love principle that Jesus has taught. Some scholars have indeed proposed some interpretations in order to 'domesticate' the psalms. Unfortunately, those interpretations have led to other problems. In this paper, the writer tries to offer an alternative interpretation toward the Imprecatory Psalms, namely understanding those psalms in the light of the Mosaic Covenant. At the end of this paper, the writer will give two practical applications from the interpretation. 
Keywords: Book of Psalms, Imprecatory Psalms, Mosaic Covenant, Old Testament, Ethic, Ethical

\section{PENDAHULUAN}

Kitab Mazmur merupakan pusat berita Perjanjian Lama ${ }^{1}$ yang unik dan penting bagi kekristenan. Di satu sisi, kitab ini unik sebab kitab ini mengandung pewahyuan istimewa yang berasal dari kehidupan batin orang-orang Israel, yang melaluinya, pembaca bisa menyelami kedalaman hati orang-orang kudus. ${ }^{2}$ Di sisi lain, kitab ini juga merupakan kitab yang penting karena banyak data sejarah, dan teologi Perjanjian Lama muncul dalam kitab ini dalam bentuk pecahan, dan tidak sistematis. ${ }^{3}$ Karena itu, bukanlah hal yang berlebihan bila dikatakan bahwa kitab ini merupakan kitab yang signifikan bagi kehidupan rohani orang Kristen. ${ }^{4}$

Meski demikian, eksistensi beberapa nomor Mazmur, ${ }^{5}$ yang lazim disebut sebagai "Mazmur Kutukan" atau "Mazmur Balas Dendam" (the Imprecatory Psalms), acapkali membingungkan orang-orang

\footnotetext{
${ }^{1}$ Tremper Longman III, Bagaimana Menganalisa Kitab Mazmur (terj. Cornelius Kuswanto; Malang: SAAT, 2007), 58.

${ }^{2}$ Julius A. Bewer, Literature of the Old Testament (New York: Columbia University, 1933), 340.

${ }^{3} \mathrm{C}$. Hassel Bullock, An Introduction to the Old Testament Poetic Books (Chicago: Moody, 1988), 139.

${ }^{4}$ Signifikansi kitab ini juga terlihat dari pengutipannya dalam Perjanjian Baru. Dari dua ratus delapan puluh tiga kutipan langsung Perjanjian Lama dalam Perjanjian Baru, seratus enam belas di antaranya merupakan kutipan dari Kitab Mazmur [Lihat Herlise Sagala, Diktat Perkuliahan Kitab Puisi (Batu: STT I-3, t.th), 115)]. Dengan kata lain, kitab ini menguasai hampir separuh kutipan langsung Perjanjian Lama dalam Perjanjian Baru. Dari data ini terlihat jelas bagaimana Kitab Mazmur begitu mempengaruhi teologi para penulis Perjanjian Baru, dan tentunya juga teologi Kristen. Bnd. Longman, Bagaimana Menganalisa Kitab Mazmur, 77.

${ }^{5}$ Beberapa orang sering salah kaprah dengan menyebut nomor Mazmur sebagai "pasal." Namun mengingat bentuk kitab Mazmur yang adalah buku doa dan nyanyian orang-orang Yahudi, maka penyebutan "nomor" jelas lebih tepat dibanding penyebutan "pasal."
} 
Kristen. Kemunculan Mazmur jenis ini telah menjadi sumber kesulitan bagi orang-orang Kristen yang saleh, dan kerap menyebabkan kemelut moral. ${ }^{6}$ Seorang penafsir lawas, Albert Barnes, bahkan menyatakan bahwa mungkin tidak ada bagian lain dalam Alkitab yang sedemikian membingungkan dan menyulitkan pembacanya seperti halnya Mazmur Kutukan. ${ }^{7}$ Inti masalah Mazmur ini sebenarnya ialah problem etis. ${ }^{8}$ Mazmur ini nampak bertentangan dengan ajaran kasih yang menjadi ciri khas Kekristenan. Menyitir pernyataan retoris Johannes Vos," Bagaimana bisa sebuah bagian dari Kitab Suci mengajarkan umat Allah mendoakan kehancuran atau malapetaka orang lain, seperti yang ada dalam Mazmur Kutukan?"' Senada dengan itu, Ray Surburg juga mempertanyakan: "How could the Holy Spirit have caused the psalm-writers to have written such unchristian statements and words?"10 Tidak bisa dipungkiri, para pembaca Alkitab yang saleh pasti mengalami kebingungan dan ketidaknyamanan ketika mereka membaca bagian-bagian seperti "Ya Allah, hancurkanlah gigi mereka dalam mulutnya, patahkanlah gigi geligi singa-singa muda, Ya Tuhan!” (Mzm. 58:7) atau "Berbahagialah orang yang menangkap dan memecahkan anak-anakmu pada bukit batu!” (Mzm. 137:9), mengingat Kristus sendiri mengajarkan,"Kasihilah musuhmu dan berdoalah bagi yang menganiaya kamu (Mat. 5:44).

\footnotetext{
${ }^{6}$ J. A. Motyer, "The Psalms," in D.A. Carson, et. al. (ed.), The New Bible Commentary (Leicester: Inter Varsity, 1994), 488.

${ }^{7}$ Albert Barnes, Notes on the Old Testament: Psalm Vol. I (Grand Rapids: Baker, 1971), Xxv.

${ }^{8}$ Bnd. J. Carl Laney, “A Fresh Look at the Imprecatory Psalms,” in Roy B. Zuck(ed), Vital Biblical Issues (Grand Rapids: Kregel, 1994), 31. ${ }^{9}$ Johannes G. Vos, "The Ethical Problem of the Imprecatory Psalms," Westminster Theological Journal 4 (May 1942): 123.

${ }^{10}$ Raymond F.Surburg, "The Interpretation of the Imprecatory Psalms," The Interpretation 39 (December 1975): 89.
} 
Akibat paradoks ini, Beardslee mencatat bahwa Mazmur Kutukan seolah cenderung "dibuang" oleh gereja. Bagian ini dilewatkan begitu saja, tidak pernah dibahas ataupun dikotbahkan, seolah-olah bagian ini tidak memiliki manfaat untuk membangun dan mendidik jemaat. ${ }^{11}$ Contoh yang paling jelas terjadi di dalam Gereja Roma Katolik. Erich Zenger, mengutip Otto Knoch, mengatakan bahwa pembacaan atau kotbah dari Mazmur Kutukan telah dihilangkan dari misa-misa maupun jam-jam liturgi Gereja Katolik Roma. ${ }^{12}$ Sedikit banyak, sikap demikian memang bisa dipahami. Akan tetapi, mengingat pernyataan Paulus di dalam 2 Timotius 3:16, maka bagian ini tentu juga "bermanfaat untuk mengajar, untuk menyatakan kesalahan, untuk memperbaiki kelakuan, dan untuk mendidik orang dalam kebenaran.” Ini penting sebab Kitab Suci yang dibicarakan Paulus di sana jelas merujuk pada Perjanjian Lama, yang tentunya juga mencakup Kitab Mazmur. Karena itu, penulis berpendapat bahwa bagian yang sulit ini tidak seharusnya dihindari, tetapi digumulkan dengan serius. ${ }^{13}$

Beranjak dari keyakinan tersebut, tulisan ini akan mencoba mengemukakan sebuah perspektif untuk memahami Mazmur Kutukan. Namun, sebelum menyampaikan perspektif tersebut,

${ }^{11}$ J.W. Beardslee, "The Imprecatory Element in the Psalms," Presbyterian and Reformed Review 8 (1897): 491.

${ }^{12}$ Erich Zenger, A God of Vengeance: Understanding the Psalms of Divine Wrath (Louisville: John Knox, 1996), 79.

${ }^{13}$ Dalam kesimpulan essainya, Jace Broadhurst mengajak untuk melihat tugas menjelaskan Mazmur Kutukan ini dari sisi teologi Biblika, yaitu supaya tugas tersebut tidak menjadi usaha harmonisasi Mazmur Kutukan dengan bagian lain dalam Alkitab (i.e. Hukum Kasih). Menurutnya, tensi yang ada bukan untuk diharmonisasi, melainkan untuk diterima ["Should Cursing Continue? An Argument for the Imprecatory Psalms in Biblical Theology,"Africa Journal for Evangelical Theology 23.1 (2004): 85-6]. Usul tersebut bisa diterima bila tensi yang ada berupa perbedaan perspektif maupun teologi penulis. Namun dalam hal tensi karena kontradiksi, seperti halnya dalam Mazmur Kutukan, tidak bisa tidak, dalam teologi Biblika pasti ada upaya harmonisasi (atau setidaknya menunjukkan bahwa hal tersebut tidak sungguh-sungguh kontradiktif). Walau tidak mengakui essainya sebagai usaha harmonisasi, tulian Broadhurst, secara filosofis, tetap mengandung unsur harmonisasi. 
tulisan ini akan lebih dulu membahas beragam interpretasi yang telah ditawarkan para sarjana untuk mendomestikasi nada-nada kutukan yang ada. Akan tetapi, pembahasan dalam bagian ini tidak ditujukan untuk menjadi pembahasan komprehensif. Penulis tidak akan membahas semua proposal, melainkan hanya akan berfokus pada beberapa proposal yang cukup populer. Penulis akan menunjukkan bahwa beragam interpretasi yang telah ditawarkan itu memiliki beberapa lubang, dan dengan demikian, kurang memadai untuk memahami Mazmur Kutukan. Setelah itu, tulisan ini baru akan menyampaikan usulan penulis, yakni memahami Mazmur Kutukan dalam covenant Musa.

\section{EVALUASI BERAGAM PROPOSAL}

Meskipun Mazmur Kutukan menimbulkan kesulitan bagi orang-orang Kristen, banyak sarjana telah menawarkan interpretasi untuk memahami Mazmur-mazmur tersebut. Dalam bagian ini, penulis akan mengevaluasi beberapa proposal penting yang telah ditawarkan untuk memahami Mazmur Kutukan. Dalam tiap proposal yang dibahas, penulis akan lebih dulu memaparkan pemikiran pandangan tersebut sebelum nantinya mengevaluasinya.

\section{Spiritualitas Perjanjian Lama yang Inferior}

Beberapa sarjana berpendapat bahwa Mazmur Kutukan merupakan hasil dari perbedaan tingkat pewahyuan di antara Perjanjian Lama dan Perjanjian Baru. Pandangan ini adalah salah satu pandangan yang paling populer untuk menjawab problematika Mazmur Kutukan. Kirkpatrick, salah seorang pendukung pandangan ini berargumen,

In what light are the utterance to be regarded? They must be viewed as belonging to the dispensation of the Old 
Testament; they must be estimated from the standpoint of the

Law, which was based upon the rule of retaliation, and not of the Gospel, which is animated by the principle of love; they belong to the spirit of Elijah, not of Christ... ${ }^{14}$

Perowne, yang juga memegang pandangan ini, mengatakan hal yang senada dengan itu, "How clearly Our Lord Himself teaches us, that His spirit and the spirit of Elijah are not the same...so...The Old Testament is not contrary to the New, but it is inferior to it." 15 Maclaren menandaskan lebih lagi:

It is far better to recognize the disordance between the temper of the Psalmist and that enjoined by Christ, than to cover it over. Our Lord has signalized the difference between his teaching and that adressed to "them of Old time' and we are but following His guidance when we reognize that the Psalmist mood is distinctly inferior to that which has now become the law for devout man $^{16}$

Dari pernyataan-pernyataan di atas terlihat jelas bahwa para pendukung pandangan ini mengasumsikan adanya perbedaan antara Perjanjian Lama dan Perjanjian Baru. Bila Perjanjian Lama menekankan hukum keadilan retributif, maka Perjanjian Baru dicirikan oleh kasih, dan pengampunan.

Driver mengamati bahwa pendukung pandangan ini menjadikan konsep pewahyuan progresif sebagai landasan berpikir mereka. Mereka berpendapat bahwa konsep pewahyuan progresif mengindikasikan bahwa masa yang lebih dulu pasti lebih kurang

\footnotetext{
${ }^{14}$ A.F. Kirkpatrick, Psalms (Grand Rapids: Baker, 1982), 1xxxix.

${ }^{15}$ J.J. Stewart Perowne, The Book of Psalms (Grand Rapids: Zondervan, 1976), 64.

${ }^{16}$ Alexander Maclaren, The Psalms Vol. 3 (New York: A.C. Armstrong and Sons, 1901), 174.
} 
sempurna, dan kurang dewasa dibanding fase yang lebih kemudian. ${ }^{17}$ Oleh karena Daud dan para penulis Mazmur hidup dalam fase yang kurang sempurna, tentu saja konsekuensinya orang-orang Kristen tidak bisa mengharapkan ajaran maupun praktik etis yang bermutu dari mereka. ${ }^{18}$ Pengamatan ini ternyata diaminkan oleh McLaren, salah seorang pendukung pandangan ini, sebab ia jelas menyatakan bahwa bentuk-bentuk kutukan dalam Mazmur merupakan hasil dari tahapan pewahyuan yang lebih rendah. ${ }^{19}$ Pendeknya, para pendukung pandangan ini berargumen bahwa Mazmur Kutukan ada dalam Alkitab untuk menunjukkan betapa berbeda seharusnya cara hidup umat Allah hari ini. Kristus telah datang dan memberi standar yang baru karena itu, umat Allah hari ini seyogyanya hidup dalam standar tersebut.

Meskipun populer, tetapi pandangan ini perlu dipertanyakan dalam tiga aspek. Pertama, pandangan ini mengabaikan fakta bahwa Perjanjian Lama juga diwarnai oleh ajaran kasih. Imamat 19:17-18, misalnya, jelas mengajarkan,

Janganlah engkau membenci saudaramu di dalam hatimu, tetapi engkau harus berterus terang menegor orang sesamamu dan janganlah engkau mendatangkan dosa kepada dirimu karena dia. Janganlah engkau menuntut balas, dan janganlah menaruh dendam terhadap orang-orang sebangsamu, melainkan kasihilah sesamamu manusia seperti dirimu sendiri; Akulah TUHAN.

Selain itu, Keluaran 23:4-5, serta Amsal 24:17 juga menunjukkan bahwa kasih bukanlah konsep yang dimonopoli oleh

\footnotetext{
${ }^{17}$ S.R. Driver, Studies in the Psalms (London: Hodder and Stoughton, 1915), 226.

${ }^{18}$ Bnd. Laney, "A Fresh Look at the Imprecatory Psalms,” 33.

${ }^{19}$ Mclaren, The Psalms, 175.
} 
Perjanjian Baru. Bahkan menarik dicatat, ketika memerintahkan kasih kepada sesama, Yesus jelas-jelas mengutip dari Perjanjian Lama! (bnd. Mat. 22:34-40).

Kedua, pandangan ini tidak tepat memahami arti dari progressive revelation. Kekristenan tradisional memang memercayai adanya pewahyuan yang progresif, yang puncaknya ada dalam diri Kristus. Akan tetapi, Archer menjelaskan bahwa pewahyuan progresif bukan berarti dari pemahaman yang salah menuju ke pemahaman yang benar, melainkan dari pewahyuan yang parsial dan tidak jelas menuju kepada pewahyuan yang lebih lengkap dan jelas. ${ }^{20}$ Terakhir, secara teologis, pandangan ini berujung pada konsep 'pengilhaman bertingkat,' yang meyakini bahwa Allah mengilhamkan Alkitab dengan derajat yang berbeda. Pemahaman ini tentu tidak sesuai dengan pernyataan Paulus bahwa semua tulisan (semua bagian Kitab Suci) adalah diilhamkan Allah atau merupakan hembusan 'isi hati' Allah. Karena tiga hal ini, penulis melihat bahwa proposal ini bukanlah cara yang memadai untuk menjelaskan Mazmur Kutukan.

\section{Kutukan Bersifat Nubuatan}

Selain melihat Mazmur Kutukan sebagai hasil spiritualitas inferior Perjanjian Lama, pandangan populer lain untuk menjelaskan Mazmur Kutukan ialah dengan menjelaskannya sebagai sebuah nubuatan. Agustinus, Calvin, Spurgeon, dan Barnes adalah beberapa contoh teolog yang memegang interpretasi ini. Para pendukung pandangan ini melihat bahwa para pemazmur bukan sekadar seorang pujangga, tetapi juga seorang nabi yang mendeklarasikan apa yang akan terjadi pada orang-orang

\footnotetext{
${ }^{20}$ Gleason L. Archer, A Survey of the Old Testament Introduction(Chicago: Moody, 1974), 460.
} 
jahat. ${ }^{21}$ Beberapa pemikir lantas memodifikasi proposal ini dan mengaitkannya dengan aspek mesianik. Salah satunya ialah teori Rekonsiliasi James E. Adam, yang menerapkan Mazmur Kutukan sebagai doa Yesus bagi musuh-musuh-Nya. ${ }^{22}$

Barnes menjelaskan argumen pandangan ini dengan baik,

Part of these passages may undoubtedly be regarded as prophetic; expressing what would be, rather than indicating any wish on the part of the author the psalms that such things should be. In some instances, the passages might have been rendered in the future instead of the imperative mood, with no violation of the laws of the Hebrew language, or the proper principles of the interpretation. Several of these passages of this kind which may properly be applied to the Messiah, are undoubtedly of this nature, and those passages are to be interpreted, when the laws of language will admit such an interpretation, as expressive of what sinners deserve, and of what will come upon them, and not as indicating any desire on the part of the author that it should be so. ${ }^{23}$

Jadi, menurut pendukung pandangan ini bentuk imperatif yang digunakan para pemazmur lebih tepat dipahami sebagai mode indikatif. Akibatnya, mereka melihat bahwa para pemazmur sebenarnya bukan sedang meminta Allah menghancurkan orangorang jahat, tetapi menyatakan apa yang akan terjadi atas mereka. Bullock memberi beberapa contoh ayat yang sering dipakai oleh penganut pandangan ini. Misalnya saat pembersihan Bait Allah, murid-murid teringat Mzm. 69:9 (Yoh. 2:17). Petrus

\footnotetext{
${ }^{21}$ Laney, "A Fresh Look at the Imprecatory Psalms," 34.

${ }^{22}$ Interpretasi Adams terlihat jelas dari bagaimana dia memberi judul bukunya, War Psalms of the Prince of Peace (Phillipsburg: P \& R, 1991). Charpentier juga senada dengan Adams dalam hal memahami Mazmur-Mazmur Kutukan bersifat mesianik. Lihat Ettiene Charpentier, Bagaimana Membaca Perjanjian Lama (Malang: Gandum Mas, 1989), 146-7.

${ }^{23}$ Barnes, Psalm Vol. I, xxx.
} 
mengaplikasikan Mzm. 69:25 dan 109:8 kepada Yudas (Kis. 1:20). Paulus juga menganggap kebutaan hukum bangsa Yahudi sebagai penggenapan Mzm. 69:22-23 (Rm. 11:9-10). ${ }^{24}$

Akan tetapi, proposal ini memiliki beberapa keberatan serius. Pertama, pandangan ini terkesan melemparkan tanggung jawab kutukan tersebut kepada Allah dan melepaskan pemazmur dari tanggung jawabnya atas kata-kata kepahitan dan balas dendam yang ada. ${ }^{25} \mathrm{Kedua}$, pandangan ini tidak bisa menjelaskan aspek nubuatan dalam nomor-nomor Kutukan yang tidak dikutip dalam Perjanjian Baru. Laney memberi contoh tentang Mazmur 137, misalnya:

The imprecation involves the third person in such a way as to show that the speaker is not simply utering the divine will as a prophet, but is expressing his own feelings as a men. Psalms 137:8-9 is an expression of the personal satisfaction the psalmist will feel when judgement overtakes the wrongdoers. ${ }^{26}$

Ketiga, pandangan ini secara implisit menyiratkan penolakan terhadap situasi kesejarahan Mazmur-Mazmur tersebut, sehingga akan menjadi sulit bagi pendukung pandangan ini untuk menjelaskan Mazmur-Mazmur Kutukan yang secara jelas mengidentifikasi musuh dan situasi kesejarahannya (mis. Mzm. 52, 54). Keempat, penggunaan tata bahasa Ibrani juga tidak mendukung pandangan ini. Sebagai contoh dalam Mzm. 69:25-26. ayat ini dimulai dengan sebuah kata kerja imperatif שפךdan diikuti oleh tiga kata kerja imperfek, yaitu תהי, ישיגם, dan יהי. Menurut aturan tata bahasa Ibrani, bila kata kerja imperfek didahului oleh sebuah kata kerja imperatif, maka kata kerja imperfek tersebut

\footnotetext{
${ }^{24}$ Bullock, An Introduction to the Old Testament, 140-1.

${ }^{25}$ Laney, "A Fresh Look at the Imprecatory Psalms," 34.

${ }^{26}$ Laney, "A Fresh Look at the Imprecatory Psalms," 35.
} 
harus diterjemahkan sebagai bentuk yusif. ${ }^{27}$ Oleh karenanya, pandangan ini jelas tidak bisa dipertahankan sebagai penjelasan yang memadai untuk Mazmur Kutukan.

\section{Ekspresi Sentimen Pribadi Daud/Pemazmur}

Solusi ketiga yang ditawarkan untuk menjelaskan Mazmur Kutukan ialah bahwa kutukan-kutukan tersebut merupakan ekspresi kemanusiaan (sentimen) Daud/pemazmur. Mazmur tersebut mencerminkan kemarahannya sebagai seorang manusia dan bukan inspirasi Roh Kudus. C.S. Lewis adalah pendukung utama pandangan ini. Ia menyebut bahwa Mazmur-Mazmur tersebut adalah produk dari "ferocious, self-pity, barbaric men." 28 Ia menganggap kutukan tersebut sebagai hal yang natural, namun ia juga meyakini bahwa hal tersebut bukanlah hasil dorongan Roh Kudus. ${ }^{29}$ Bright menambahkan bahwa ekspresi kemanusiaan yang seperti demikian tidak untuk disetujui, tapi untuk dimengerti sebagai kebutuhan manusia akan Kristus. ${ }^{30}$ Craigie merangkumkan pokok pemikiran pandangan ini sebagai berikut,

..the words of psalmist are often natural and spontanaeous, not always pure and good, and yet they reflect the intimacy of the relationship between psalmist and God. The exprssion of hatred is in a way a confession of sin, though it is not phrased as such; it is

${ }^{27}$ Lihat E. Kautzch (ed.), Gesenius Hebrew Grammar (Oxford: Clarendon, 1910), 322. Bentuk yusif adalah kata kerja imperfek atau perfek konsekutif orang ketiga yang dipakai dalam arti perintah tidak langsung atau permintaan. Lihat T.G.R. Boeker, Ibrani II (Batu: Institut Injil Indonesia, 2003), 10

${ }^{28}$ C.S. Lewis, Reflection on the Psalms (New York: HJB, 1958), 24. Kittel sepemikiran dengan Lewis, dengan menyebut Mazmur-Mazmur tersebut berasal dari individu yang berjiwa kotor, yang hanya memikirkan penaklukan dan balas dendam. Lihat G.S. Gunn, God in the Psalms (Edinburgh; Saint Andrew, 1962), 102.

${ }^{29}$ Lewis, Reflection on the Psalms, 110-12.

${ }^{30}$ John Bright, The Authority of the Old Testament (Nashville: Abingdon, 1967), 238. 
a part of the inner life of a person which may be cleansed and transformed through the relationship with God. ${ }^{31}$

Seandainya pandangan ini dipertahankan, maka pendukung pandangan ini akan menghadapi beberapa problem. Pertama, proposal ini mungkin bisa dimengerti seandainya Mazmur-Mazmur ini ditulis segera setelah konflik terjadi. Akan tetapi, Broadhurst mengingatkan bahwa Mazmur-mazmur Kutukan sangat mungkin ditulis dan direvisi beberapa saat sesudah konflik terjadi atau selesai, sehingga tekanan konflik tentunya juga jauh lebih berkurang. ${ }^{32}$ Senada dengan itu, Day juga berpendapat bahwa,

"...to explain the imprecatory psalms as outburst of evil emotion may account for the initial writing of the psalms, but it does not adequately explain why these psalms were included in the psalter, the book of worship for God's people.",33

Kedua, pandangan ini terlihat menolak kepengarangan Ilahi (Divine authorship) dalam usahanya yang "semena-mena" untuk membedakan ekspresi kemanusiaan dan ekspresi dari Roh. Padahal konsep pengilhaman tradisional meyakini bahwa Allah memakai penulis Kitab Suci dengan segala keberadaannya sebagai satu pribadi yang utuh. Allah memakai segenap pikiran, perasaan, karakter, penyelidikannya, gaya penulisan, dan kepribadiannya. Ini berarti pandangan ini telah membuat dikotomi yang tidak perlu, yang justru menjadikan mereka gagal memahami kesatuan antara kepengarangan Ilahi dan insani.

\footnotetext{
${ }^{31}$ Peter C. Craigie, Psalms 1-50 (WBC; Waco: Word Books, 1983), 41.

${ }^{32}$ Broadhurst, "Should Cursing Continue?", 75.

${ }^{33}$ John N. Day, "The Inprecatory Psalms and Christian Ethics," Bibliotheca Sacra 159 (April-June 2002): 167.
} 
Ketiga, secara teologis, pandangan ini jatuh pada apa yang disebut sebagai "pengilhaman parsial," yang meyakini bahwa tidak semua bagian dalam Kitab Suci diilhamkan oleh Allah. Hal ini jelas bertentangan dengan fakta bahwa seluruh Alkitab adalah diilhamkan Allah (2 Tim. 3:15-16). Bahkan dalam sebuah nats Kutukan yang dikutip dalam Perjanjian Baru, penulis Perjanjian Baru yang mengutipnya menegaskan otoritas nats tersebut sebagai diilhamkan (Kis. 1:16). Mengingat problem-problem ini, maka penulis memandang proposal ini tidak bisa diterima sebagai solusi.

\section{Kutukan Ditujukan Terhadap Musuh-Musuh Rohani}

Pandangan keempat adalah pandangan yang dimunculkan oleh Sigmund Mowinckel, murid seorang pakar Perjanjian Lama, Herman Gunkel. Ia berpendapat bahwa kutukan-kutukan tersebut diutarakan atas nama Allah melawan kuasa-kuasa kegelapan dengan tujuan mengalahkan kekuatan jahat yang menyiksa pemazmur. ${ }^{34}$ Broadhurst menyebut "kelebihan" pandangan ini ialah bahwa karena musuh yang dimaksud bersifat rohani, maka tidak akan ada dosa terhadap sesama, karena hukum (Taurat) tidak untuk diaplikasikan pada Iblis. ${ }^{35}$ Finalnya, juga tidak akan ada masalah etis yang perlu dirisaukan.

Penulis menyangsikan akurasi pandangan ini mengingat pandangan ini tidak bisa menjelaskan keberadaan musuh yang teridentifikasi dengan jelas, misalnya Doeg (Mzm. 52:1). Selain itu bila memang musuh yang dimaksud adalah realitas spiritual, maka Mazmur 109 akan menjadi mazmur yang aneh, sebab mazmur ini menyebut bahwa "musuh spiritual" tersebut memiliki keluarga (istri, anak). Lebih-lebih teks kutukan akan terasa lebih natural bila

\footnotetext{
${ }^{34}$ Lihat Sigmund Mowinckel, The Psalms in Israel's Worship Vol. 2(New York: Abingdon, 1962), 44-52.

${ }^{35}$ Broadhurst, "Should Cursing Continue?", 73.
} 
dipahami untuk ditujukan kepada musuh jasmani ketimbang lawan non-jasmani. ${ }^{36}$ Bahkan secara teologis, bila memang obyek kutukan ini adalah kuasa-kuasa kegelapan, berarti kutukan ini tidak memiliki signifikansi apapun, mengingat kutukan Allah terhadap Iblis dalam Kej. 3:14-15 yang sudah ada lebih dulu. Mengingat problem dengan proposal ini, tidak mengherankan bila Barth dan Pareira menuliskan bahwa pandangan ini sebenarnya tidak terbukti keabsahannya. ${ }^{37}$

\section{Kutukan Ditulis Orang Lain}

Beberapa orang menganggap bahwa kutukan-kutukan dalam Kitab Mazmur bukan ditulis oleh Daud, sehingga konsekuensinya, kutukan-kutukan ini pasti tidak diilhamkan, dan oleh karenanya, bisa diabaikan. ${ }^{38}$ Pendukung pandangan ini mendasarkan argumennya pada polemik penerjemahan preposisi $ל$ di depan nama Daud. Mereka berpendapat bahwa preposisi tersebut tidak untuk diartikan sebagai rujukan kepengarangan, melainkan sebuah informasi bahwa Mazmur-mazmur tersebut didedikasikan untuk Daud. Secara teologis, ini menunjukkan bahwa pendukung pandangan ini mengasumsikan adanya keterkaitan erat antara otoritas Alkitab dengan identifikasi penulisnya. Problem dengan

\footnotetext{
${ }^{36}$ Bnd. N. H. Ridderbos and Peter C. Craigie, "Psalms" in Geoffrey W. Bromiley (ed), The International Standard Bible Encyclopedia (Grand Rapids: Wm. B. Eerdmans, 1988), 1035. Laney juga keberatan terhadap terhadap pendekatan pandangan ini. Dia menulis, "How is one to determine when to make the transition from a literal to a spiritual interpretation of a particular passage?" (Laney, "A Fresh Look at the Imprecatory Psalms,"34). Meski Broadhurst menyebut argumen Laney ini tidak fair dan tidak akademis (Broadhurst, "Should Cursing Continue?", 74), pertanyaan Laney sebenarnya tetap valid, mengingat konteks dekat Mazmur-Mazmur tersebut memang tidak mengarah pada proposal yang diajukan Mowinckel. Bukankah konteks dekat merupakan kontrol yang paling penting? Bnd. D. A. Carson, Kesalahan-Kesalahan Eksegetis (terj. Lanna Wahyuni; Surabaya: Momentum, 2009), 83-4.

${ }^{37}$ Marie C. Barth dan B.A. Pareira, Kitab Mamur 1-72 (Jakarta: BPK Gunung Mulia, 1998), 99.

${ }^{38}$ Bnd. Broadhurst, "Should Cursing Continue?," 69.
} 
pandangan ini terletak pada dasarnya yang rapuh. Para sarjana berpendapat bahwa preposisi ל tidak selalu berarti tujuan. Dalam kasus, preposisi ini juga bisa berarti asal atau sumber. Namun andaikata pun Mazmur ini ditulis bukan oleh Daud, argumen ini tetap tidak bisa menjelaskan mengapa Mazmur yang demikian dimasukkan dalam buku pujian dan doa orang-orang kudus. Terakhir, pandangan ini juga salah memahami sumber otoritas Kitab Suci. Sumber otoritas Kitab Suci terletak bukan pada siapa penulisnya, tapi pada siapa yang mengilhamkannya. Bukankah yang diinspirasikan Allah adalah tulisannya dan memang bukan penulisnya? (2 Tim. 3:16)

Beberapa orang memodifikasi pandangan ini dengan menegaskan bahwa Mazmur Kutukan sebenarnya ditulis oleh musuh-musuh Daud. Abineno (mengikuti jejak Krauss) merupakan salah satu pendukung pandangan ini. Dalam studinya atas Mazmur 109, ia mengatakan bahwa di akhir ay. 5, nampaknya terjadi(penghilangan)kata לאמר dari teks. Ia lantas menyimpulkan bahwa ay. 5-20 sebenarnya merupakan ungkapan kutukan musuhmusuh Daud terhadapnya dengan ay. 17-19 menjadi alasannya. ${ }^{39}$ Sayangnya, interpretasi ini cenderung dipaksakan. Selain tidak adanya petunjuk yang jelas mengenai peralihan subyek ${ }^{40}$ maupun dukungan teks yang kuat tentang penghilangan kata לאמר di ay. 5, pandangan yang dikemukakan Abineno ini, justru menimbulkan kontradiksi alur cerita. Bila memang ay, 17-19 merupakan alasan musuh-musuh Daud mengutuki Daud, maka hal itu akan bertentangan dengan pernyataan Daud di ay. 3-5, bahwa pada dasarnya musuh-musuhnya memeranginya tanpa alasan dan membalas kebaikannya dengan kejahatan. Leslie Allen, yang menerapkan analisa bentukpada Mazmur 109 juga menunjukkan

\footnotetext{
${ }^{39}$ J.L. Ch. Abineno, Mazmur dan Ibadah (Jakarta: BPK Gunung mulia, 1987), $161-2$.

${ }^{40}$ Laney, “A Fresh Look at the Imprecatory Psalms”, 32-3.
} 
kesatuan Mazmur ini secara konstruktif. Ia menulis bahwa Mazmur ini memiliki konstruksi berpalang dengan pola ABA'B', dengan strophe $\mathrm{B}$ salah satunya melanjutkan strophe A sebagai deskripsi terhadap strophe A. ${ }^{41}$ Oleh karenanya akan lebih tepat untuk memahami konsistensi alur Mazmur ini daripada mempercayai adanya peralihan tokoh. Selain itu, andaikata pun interpretasi ini bisa menjelaskan Mazmur 109, interpretasi ini gagal menjelaskan nomor-nomor lain seperti Mazmur 6, 7, 10, 17, dan sebagainya. Karena itu, pandangan ini pun tidak memadai menjadi penjelasan yang baik terhadap problematika ini.

\section{Kutukan Ditujukan terhadap Dosa, Bukan Pendosa}

John L. Mckenzie, salah satu pendukung utama pandangan ini, mengatakan bahwa ungkapan kebencian yang ada dalam Mazmur Kutukan sebenarnya ditujukan kepada hal yang memang layak untuk dibenci, yakni dosa seseorang. ${ }^{42}$ Ia meyakini bahwa kutukan-kutukan tersebut pasti disertai oleh kasih terhadap pendosa, sebab menurutnya seorang pendosa dapat secara sah dibenci hanya saat dia (pendosa) dikasihi. Oleh karena disertai rasa kasih, maka pasti ada harapan pertobatan di dalamnya, yang bila pertobatan itu terjadi, maka hukuman Ilahi pasti dihilangkan. Namun, andaiakata pun hukuman Ilahi itu terjadi, maka yang terjadi ialah hukuman Ilahi dan bukannya dendam pemazmur. ${ }^{43}$ Dari silogisme ini, ia menyimpulkan bahwa kutukan-kutukan

\footnotetext{
${ }^{41}$ Konstruksi Mazmur ini adalah sebagai berikut:

A. ay. 1-5.

B. ay. 6-20.

A'. ay. 21-26.

B'. ay. 26-31.

Bnd. Leslie C. Allen, Psalms 101-150: Word Biblical Commentary; Dallas:

Word Books, 1990), 96-101.

${ }^{42}$ John L. McKenzie, "The Imprecation of the Psalter," American Ecclesistical

Review 111 (1994): 90.

${ }^{43}$ McKenzie, "The Imprecation of the Psalter", 92-93.
} 
tersebut jelas ditujukan pemazmur kepada dosa, dan bukannya pada si pendosa. Akan tetapi, problem utama pandangan ini ialah bahwa sangat sulit untuk memisahkan (atau setidaknya) membedakan kebencian seseorang terhadap dosa dengan kebencian terhadap pendosa. Terlebih, anthropologi Yahudi cenderung melihat manusia secara utuh sebagai satu kesatuan yang tak dapat dipisahkan, termasuk juga sifat-sifat yang melekat pada seseorang. Benson juga sependapat bahwa dalam bahasa Mazmur nampaknya memang tidak ada pembedaan antara dosa dan orang berdosa. ${ }^{44}$ Oleh sebab itu, pandangan yang didukung McKenzie ini pun jelas bukan solusi yang tepat untuk memahami Mazmur Kutukan.

\section{Kutukan Diungkapkan Melawan Musuh Allah}

Pandangan terakhir yang penulis bahas ialah bahwa kutukankutukan tersebut ditujukan terhadap musuh-musuh Allah. Martin, Archer, Jensen, dan Purkiser adalah contoh-contoh penganut pandangan ini. Archer menulis bahwa di dalam Mazmur-Mazmur kutukan, pemazmur sebenarnya sedang melakukan hal ini:

Identifying himself completely with God's cause, he could only regard God's enemies as his own, and implore God to uphold His own honor and justify His own righteousness by inflicting a crushing destruction upon those who either in theory or in practice denied His sovereignty and His law ${ }^{45}$

Martin juga mengutip dari Mzm. 5:10 untuk mendukung pandangan ini. ${ }^{46} \mathrm{Jadi}$, bagi pendukung pandangan ini, musuh-

\footnotetext{
${ }^{44}$ Clarence H. Benson, Pengantar Perjanjian Lama: Puisi dan Nubuat (Malang: Gandum Mas, 1983), 20.

${ }^{45}$ Archer, A Survey of the Old Testament, 437.

${ }^{46}$ Chalmer Martin, "The Imprecations in the Psalms"in Walter C.Kaiser, Jr (ed.), Classical Evangelical Essays in Old Testament Interpretation (Grand Rapids: Baker, 1972), 126.
} 
musuh pemazmur dan Israel pada dasarnya dan utamanya ialah musuh dari Allah. Sayangnya, proposal ini memiliki problem serius dalam identifikasinya yang terbalik. Pemazmur di sini tidak sedang mengidentikkan musuh Allah sebagai musuhnya, melainkan justru sebaliknya, menganggap musuhnya sebagai musuh Allah juga. ${ }^{47}$ Teks-teks Kutukan dengan jelas menunjukkan bahwa konflik yang ditulis terjadi antara pemazmur dan musuhnya, bukan antara Allah dan musuhnya. Musuh yang termaktub dalam nats-nats Kutukan memang juga adalah musuh Allah, namun bukan dalam pengertian "langsung," melainkan 'tidak langsung.' Identifikasi yang salah ini juga menunjukkan bahwa pandangan ini pun tidak bisa untuk menjadi solusi yang memuaskan.

\section{Konklusi}

Pandangan-pandangan di atas adalah solusi-solusi yang pernah dimunculkan untuk menjawab problematika Mazmur Kutukan. Sayangnya, solusi-solusi itu tidak secara tuntas menjawab permasalahan, karena dalam beberapa poin pandangan-pandangan tersebut justru menimbulkan kesulitan yang lain. Oleh karenanya, sejauh ini bisa disimpulkan bahwa pandangan-pandangan yang pernah dimunculkan tersebut tidak bisa menjadi solusi yang tepat untuk problematika ini. Namun bagaimanapun, penghargaan tetap layak diberikan atas upaya orang-orang tersebut. Dalam bagian selanjutnya, penulis akan memaparkan solusi yang penulis anggap lebih tepat untuk menjelaskan Mazmur Kutukan.

\section{PROPOSAL BARU}

Sebelum melangkah lebih jauh, ada dua hal penting yang perlu dipahami terkait bahasa yang kasar dari Mazmur Kutukan. Yang pertama adalah sifat blak-blakan dari budaya Ibrani. Budaya

\footnotetext{
${ }^{47}$ Bnd. Mis. Mzm. 5:9; 7:2ff; 17:9ff; 18:18ff, dsb.
} 
Ibrani merupakan budaya yang cenderung tanpa penjelasan. Hal ini terlihat jelas dari bahasa mereka yang terus terang dan konkrit, tidak abstrak. ${ }^{48}$ Bagi budaya ini, kata-kata yang keras dan bahasa kutukan nampaknya bukanlah hal yang tabu sebagaimana dipahami kini (bnd. Mis. 2 Sam: 16:5, 9; 2 Raj. 2:23-25). Budaya ini tentu berbeda tajam dari kebanyakan budaya sekarang yang mengedepankan norma 'kesopanan.' Perbedaan budaya ini nampaknya menjadi alasan utama mengapa pembaca modern sukar memahami hal ini. Meski demikian, perbedaan budaya ini juga mengingatkan pembaca modern untuk tidak langsung menilai secara serampangan.

Kedua, budaya ini juga gemar menggunakan bahasa puitis atau kiasan (majas). Di antara sekian banyak majas, salah satu majas yang cukup dominan digunakan ialah majas hiperbola, yakni bahasa kiasan yang bertujuan membesar-besarkan atau melebihlebihkan sesuatu. Salah satu contoh yang menonjol ialah dalam Mzm. 6:7, yang di dalamnya Daud menuliskan: "Lesu aku karena mengeluh; setiap malam aku menggenangi tempat tidurku, dengan air mataku aku membanjiri ranjangku." Di dalam ayat ini, tentunya, Daud tidak sungguh-sungguh bermaksud bahwa setiap malam dia (secara literal) membanjiri ranjangnya dengan air matanya. Ungkapan tersebut hanyalah sebuah bahasa kiasan yang menunjukkan bagaimana berat dan banyaknya masalah Daud.

Dua hal penting ini diingat karena menjelaskan kemunculan bahasa yang tajam di dalam Mazmur Kutukan. Kedua hal ini memang tidak menjelaskan apa yang hendak disampaikan oleh Mazmur Kutukan, tetapi dua hal ini membantu pembaca modern menjelaskan istilah-istilah yang tajam seperti "mematahkan gigi" ataupun "menghancurkan anak-anak." Selain itu, dua hal ini

\footnotetext{
${ }^{48}$ Benson, Pengantar Perjanjian Lama, 20.
} 
menegaskan bahwa bahasa yang kasar dari pemazmur tidak untuk diterapkan atau diteladani secara harafiah. Bahasa yang kasar tersebut merupakan produk budaya Ibrani kuno, bukan kebenaran kekal. Apa yang harus pembaca modern teladani ialah sikap teologis yang hendak disampaikan oleh pemazmur. Bila demikian, apakah yang sebenarnya pemazmur sedang coba sampaikan?

Carl Laney ${ }^{49}$ sangat tepat menyatakan bahwa pemahaman Mazmur Kutukan harus dimulai dari covenant, ${ }^{50}$ sebab covenant memang memiliki pengaruh yang besar dalam keseluruhan Perjanjian Lama. ${ }^{51}$ Eichrodt menulis, "The concept in which Israelite thought gave definitive expression to binding of the people to God and by means of which they established firmly from the start the particularity of their kowledge of him was covenant"52 Senada dengan Eichrodt, Dyrness mencatat bahwa covenant adalah inti pengertian orang Ibrani tentang hubungan mereka dengan Allah. ${ }^{53}$ Dengan kata lain, melalui covenant, seseorang dapat melihat dan memahami konsistensi dan keterkaitan karya Allah pada umat pilihan-Nya dalam Perjanjian Lama. Karena itu, tidaklah

\footnotetext{
${ }^{49}$ Laney, "A Fresh Look at the Imprecatory Psalms", 36.

${ }^{50}$ Penulis memilih tidak menerjemahkan $b^{e}$ rît ke dalam bahasa Indonesia sebagai "perjanjian," karena kata "perjanjian" terlalu luas untuk memuat makna kata $b^{e}$ rît. Oleh karenanya penulis memutuskan untuk menerjemahkan $b^{e}$ rît ke dalam istilah Inggris, covenant, dengan pertimbangan konsensus yang ada, bahwa kata ini lebih baik merepresentasikan makna kata $b^{e}$ rît. Penulis juga tidak setuju dengan usaha beberapa orang yang menerjemahkan covenant sebagai 'kovenan,' karena bagi penulis hal tersebut bukan menerjemahkan tapi hanya sekadar mentransliterasikan kata covenant. Lihat misalnya contoh terjemahan ini dalam Richard L. Pratt, Jr., Dia Berikan Kisah-Nya (Surabaya: Momentum, 2005); Anthony A. Hokema, Diselamatkan Oleh Anugerah (Surabaya: Momentum, 2002).

${ }^{51}$ George A. F. Knight, A Christian Theology of the Old Testament (Richmond: John Knox, 1959), 218.

${ }^{52}$ Walter Eichrodt, Theology of the Old Testament Vol. 1 (Philadelphia:

Westminster Press, 1961), 36.

${ }^{53}$ William Dyrness, Tema-Tema Dalam Teologi Perjanjian Lama (Malang: Gandum Mas, 1992), 95.
} 
berlebihan bila dikatakan bahwa covenant merupakan benang merah untuk memahami teologi para penulis Perjanjian Lama.

Akan tetapi, tidak seperti Laney yang menganggap covenant Abraham sebagai kunci memahami Mazmur Kutukan, penulis justru melihat covenant dengan Musa sebagai titik pemahaman yang tepat. Di dalam covenant ini, Allah memberikan beragam ketentuan kepada umat-Nya, yang mencakup relasi mereka dengan Allah maupun dengan sesama. Dyrness menggolongkan beragam ketentuan itu ke dalam dua model, yakni hukum apodiktis ("Janganlah kamu") dan hukum retributif (Jika kamu ... maka kamu akan ...). ${ }^{54}$ Di dalam perkembangan selanjutnya, hukum yang terakhir ini nampak lebih dominan memengaruhi konsep berpikir bangsa Israel. Hukum retributif mengajar bahwa bila bangsa Israel berelasi dengan benar terhadap Allah dan sesama, maka Allah akan memberkati mereka (mis. Ul. 28:1-14; 16:20; 24:10-13, 19-22). Tetapi, bila mereka meninggalkan Allah atau berbuat tidak adil terhadap sesama, maka Allah akan murka dan menghukum mereka (mis. Ul. 28:15-46; Kel. 22:21-27). Dengan demikian, di satu sisi, Allah akan menjadi pembela umat yang setia. Dia juga akan menjadi penolong bagi yang tertindas. Tetapi di sisi lain, Dia akan menghukum setiap orang yang melanggar perjanjian dan ketentuan-ketentuan-Nya. Meski hukum ini memang dibuat dalam konteks relasi komunal bangsa Israel, tetapi tidak bisa disangkal bahwa implikasinya pasti terasa dalam skala interpersonal.

Bila hal ini diterapkan pada Mazmur Kutukan, maka penulis memahami nada-nada kutukan tersebut sebagai doa kepada Allah supaya Dia menjadi pembela yang menyatakan keadilan-Nya. Satu hal penting yang tidak boleh dilupakan ialah bahwa nada-nada

\footnotetext{
${ }^{54}$ Dyrness, Tema-Tema Dalam Teologi Perjanjian Lama, 101.
} 
kutukan yang ada merupakan reaksi atas ketidakadilan yang dilakukan orang-orang jahat terhadap pemazmur/umat Allah. Musuh-musuh itu memburu orang yang tertindas dan menjebaknya dalam tipu daya (10:2), berusaha untuk menjatuhkan pemazmur (17:4), ingin mencabut nyawa orang yang dipilih (35:4), mengadakan permufakatan licik melawan umat pilihan Allah (83:4), dsb. Di sepanjang Mazmur Kutukan, nuansa bahwa telah terjadi ketidakadilan dan penindasan akan selalu terasa. Ikatan covenant menjadikan kejahatan tersebut sebenarnya diarahkan pula kepada Allah yang benar. Akibatnya, para pelaku kejahatan tersebut sebenarnya juga sedang melawan Allah. Ketika para musuh menindas umat pilihan Allah, itu berarti mereka melawan Allah yang menjadi raja mereka. Demikian pun ketika, beberapa orang Israel menindas sesamanya, itu berarti mereka sedang melawan Allah yang memberi peraturan dan yang menjadikan diriNya sebagai pembela orang tertindas.

Dalam keadaan demikian, pemazmur sangat berhak untuk memohon Allah tampil menjadi pembela dan menegakkan keadilan-Nya, sebab Yahwe sendiri telah berjanji akan menjaga, melindungi umat pilihan-Nya; Dia berjanji akan menjadi pembela bagi orang-orang yang mengalami ketidakadilan dan penindasan. Oleh karena itu, Daud, yang setia menjadikan Yahweh sebagai Allahnya, ${ }^{55}$ berhak untuk menuntut realisasi janji itu ketika dia sedang terancam ataupun teraniaya oleh musuh-musuhnya. Hal yang sama belaku pula pada pemazmur anonim (Mzm. 71:1) dan Asaf yang berbicara atas nama umat pilihan (Mzm. 79:1, 9; 83:2, 4, 17-19). Mzm. 137 memang tidak secara eksplisit menyebut bahwa umat pilihan menjadikan Yahweh sebagai Allah mereka, tetapi pengalamatan Mazmur tersebut kepada Yahweh (137:7), menjadi bukti penting bahwa umat pilihan sedang menjadikan Yahweh

\footnotetext{
${ }^{55}$ Bnd. Mzm. 5:3; 7:2; 9:3; 17:6; 18:2-3; 21:8; 28:1, dsb.
} 
sebagai Allah mereka, dan karenanya, mereka pun berhak menuntut janji itu.

\section{PENUTUP DAN IMPLIKASI}

Tidak bisa dipungkiri Mazmur Kutukan telah menimbulkan kesulitan di dalam sejarah. Meski demikian, beberapa orang telah menawarkan beberapa alternatif penjelasan untuk memahami fenomena ini. Sayangnya, penjelasan-penjelasan yang ditawarkan itu, dalam pandangan penulis, tidak memberikan proposal yang memadai untuk memahaminya. Di dalam tulisan ini, penulis berpendapat bahwa Mazmur tersebut harus dipahami dalam terang covenant Musa. Secara ringkas, Mazmur Kutukan merupakan ungkapan memohon keadilan Allah yang dibalut dalam gaya bahasa zaman itu, yakni gaya bahasa yang blak-blakan dan hiperbolis. Karena itu, apa yang patut diteladani bukanlah fenomena bahasa yang keras dari Mazmur ini, melainkan noumenanya, yakni permintaan supaya Allah menjadi pembela orang benar.

Dari pembahasan ini ada dua implikasi praktis yang penulis tarik. Pertama, Mazmur Kutukan mengajar bahwa umat Tuhan memiliki hak untuk menuntut keadilan Allah. Hanya saja, sebagaimana para pemazmur menyerahkan segalanya dalam tangan Tuhan, bahkan perasaan kebencian mereka, ${ }^{56}$ maka tuntutan ini tidak boleh dilandaskan pada kebencian pribadi tapi pada kerinduan akan kemuliaan Allah. ${ }^{57}$ Ajaran demikian ini bukanlah ajaran yang tidak alkitabiah. Nyatanya, ajaran ini tetap muncul dalam Perjanjian Baru, ketika Paulus memohon keadilan Allah atas Aleksander yang telah banyak menjahatinya (2 Tim. 4:14), dan juga saat jiwa-jiwa yang mati karena firman Allah menuntut

\footnotetext{
${ }^{56}$ Zenger, A God of Vengeance, 79.

${ }^{57}$ Bnd. Broadhurst, "Should Cursing Continue?", 80.
} 
pembalasan atas darah mereka (Why. 6:10). Bahkan secara implisit ajaran ini juga muncul dalam doa yang Tuhan Yesus sendiri ajarkan, yaitu doa Bapa Kami. Ketika umat Tuhan berdoa,"Bapa kami yang di sorga, Dikuduskanlah nama-Mu, datanglah Kerajaan-Mu, jadilah kehendak-Mu di bumi seperti di sorga," itu berarti umat Tuhan sedang memohon supaya Iblis dan para pengikutnya jatuh dan menerima hukuman yang mereka pantas terima. Kehendak Allah di bumi tidak akan sama seperti di sorga tanpa Allah menghancurkan Iblis dan orang-orang fasik. Green juga menyebut bahwa doa umat Tuhan hari ini yang sering memohon supaya Tuhan segera datang kembali, pada dasarnya senada dengan tuntutan ini, sebab dengan berdoa demikian, secara tidak langsung, umat Tuhan sedang memohon supaya Allah segera menegakkan keadilan-Nya dan memusnahkan semua orang fasik dari muka bumi. ${ }^{58}$

Kedua, Mazmur kutukan mengajar umat Tuhan untuk selalu mengandalkan Tuhan saat mengalami penindasan. Menariknya, Mazmur Kutukan mengajar bahwa tindakan tersebut adalah tindakan yang tak terkondisi. Sebagaimana bangsa Yehuda (yang tak berdaya di bawah penjajahan dan penindasan) ataupun Daud (yang sebenarnya memiliki kekuatan untuk menghancurkan sendiri musuh-musuhnya) mengandalkan Tuhan, demikian pun harusnya umat Tuhan. Entahkah umat Tuhan sama seperti bangsa Yehuda yang tak berdaya dalam menghadapi penindasnya, ataupun seperti Daud, yang memiliki kekuatan untuk melawan, umat Tuhan harus tetap mengandalkan Tuhan dalam segala kondisi, dan tidak mengandalkan kekuatan diri sendiri ataupun orang lain dalam menghadapi penindasan tersebut. Implikasi ini juga menunjukkan konsistensi Mazmur Kutukan dengan dengan ajaran kasih. Sebab ketika Tuhan Yesus mengajarkan supaya umat Tuhan berdoa bagi

\footnotetext{
${ }^{58}$ Dennis Green, Pembimbing Pada Pengenalan Perjanjian Lama (Malang: Gandum Mas, 2001), 135.
} 
yang menganiaya mereka (Mat. 5:44), Ia juga sedang mengajak umat Tuhan untuk mengandalkan Tuhan. Dengan kata lain, dalam bahasa Rasul Paulus, Ia sedang mengajarkan umat-Nya untuk “...memberi tempat pada murka Allah, sebab ada tertulis: pembalasan itu adalah hak-Ku” (Rm. 12:19). Ini memang tidak berarti umat Allah lantas bertindak pasif. Umat Allah berhak mengambil langkah-langkah yang sah untuk mengatasi penindasan, tetapi di atas semua itu mereka harus percaya bahwa Allah adalah pembela ultimat mereka.

\section{DAFTAR RUJUKAN}

Abineno, J.L. Ch. Mazmur dan Ibadah (Jakarta: BPK Gunung mulia, 1987)

Adams, James E. War Psalms of the Prince of Peace (Phillipsburg: $\mathrm{P} \& \mathrm{R}, 1991)$.

Allen, Leslie C. Psalms 101-150: Word Biblical Commentary; Dallas: Word Books, 1990)

Archer, Gleason L. A Survey of the Old Testament Introduction (Chicago: Moody, 1974).

Barnes, Albert. Notes on the Old Testament: Psalm Vol. I (Grand Rapids: Baker, 1971).

Barth, Marie C. dan B.A. Pareira, Kitab Mamur 1-72 (Jakarta: BPK Gunung Mulia, 1998)

Beardslee, J.W. "The Imprecatory Element in the Psalms," Presbyterian and Reformed Review 8 (1897): 490-505. 
54 (Sebuah Upaya) Memahami Mazmur Kutukan

Benson, Clarence H. Pengantar Perjanjian Lama: Puisi dan Nubuat (Malang: Gandum Mas, 1983)

Bewer, Julius A. Literature of the Old Testament (New York: Columbia University, 1933).

Boeker, T.G.R. Ibrani II (Batu: Institut Injil Indonesia, 2003).

Bright, John. The Authority of the Old Testament (Nashville: Abingdon, 1967)

Broadhurst, Jace. "Should Cursing Continue? An Argument for the Imprecatory Psalms in Biblical Theology," Africa Journal for Evangelical Theology 23.1 (2004): 61-89

Bromiley, Geoffrey W (ed). The International Standard Bible Encyclopedia (Grand Rapids: Wm. B. Eerdmans, 1988)

Bullock, C. Hassel. An Introduction to the Old Testament Poetic Books (Chicago: Moody, 1988)

Carson, D.A. et. al. (eds). The New Bible Commentary (Leicester: Inter Varsity, 1994)

Carson, D. A. Kesalahan-Kesalahan Eksegetis (terj. Lanna Wahyuni; Surabaya: Momentum, 2009)

Charpentier, Ettiene. Bagaimana Membaca Perjanjian Lama (Malang: Gandum Mas, 1989)

Craigie, Peter C. Psalms 1-50 (WBC; Waco: Word Books, 1983)

Day, John N. "The Imprecatory Psalms and Christian Ethics," Bibliotheca Sacra 159 (April-June 2002): 166-186. 
Driver, S.R. Studies in the Psalms (London: Hodder and Stoughton, 1915).

Dyrness, William. Tema-Tema Dalam Teologi Perjanjian Lama (Malang: Gandum Mas, 1992)

Eichrodt, Walter. Theology of the Old Testament Vol. 1 (Philadelphia: Westminster Press, 1961).

Green, Dennis. Pembimbing Pada Pengenalan Perjanjian Lama (Malang: Gandum Mas, 2001)

Gunn, G.S. God in the Psalms (Edinburgh: Saint Andrew, 1962).

Hokema, Anthony A. Diselamatkan Oleh Anugerah (Surabaya: Momentum, 2002).

Kaiser, Jr., Walter C (ed), Classical Evangelical Essays in Old Testament Interpretation (Grand Rapids: Baker, 1972).

Kautzch, E. (ed). Gesenius Hebrew Grammar (Oxford: Clarendon, 1910)

Kirkpatrick, A.F. Psalms (Grand Rapids: Baker, 1982).

Knight, George A. F. A Christian Theology of the Old Testament (Richmond: John Knox, 1959)

Lewis, C.S. Reflection on the Psalms (New York: HJB, 1958)

Longman III, Tremper. Bagaimana Menganalisa Kitab Mazmur (terj. Cornelius Kuswanto; Malang: SAAT, 2007). 
56 (Sebuah Upaya) Memahami Mazmur Kutukan

Maclaren, Alexander. The Psalms Vol. 3 (New York: A.C. Armstrong and Sons, 1901).

McKenzie, John L. "The Imprecation of the Psalter," American Ecclesiastical Review 111 (1994): 81-96.

Mowinckel, Sigmund. The Psalms in Israel's Worship Vol. 2 (New York: Abingdon, 1962)

Perowne, J.J. Stewart. The Book of Psalms (Grand Rapids: Zondervan, 1976).

Pratt, Jr., Richard L. Dia Berikan Kisah-Nya (Surabaya: Momentum, 2005)

Sagala, Herlise. Diktat Perkuliahan Kitab Puisi (Batu: STT I-3, t.th)

Surburg, Raymond F. "The Interpretation of the Imprecatory Psalms," The Interpretation 39 (December 1975):88-102

Vos, Johannes G. "The Ethical Problem of the Imprecatory Psalms," Westminster Theological Journal 4 (May 1942):123-38

Zenger, Erich. A God of Vengeance: Understanding the Psalms of Divine Wrath (Louisville: John Knox, 1996).

Zuck, Roy B. (ed). Vital Biblical Issues (Grand Rapids: Kregel, 1994). 